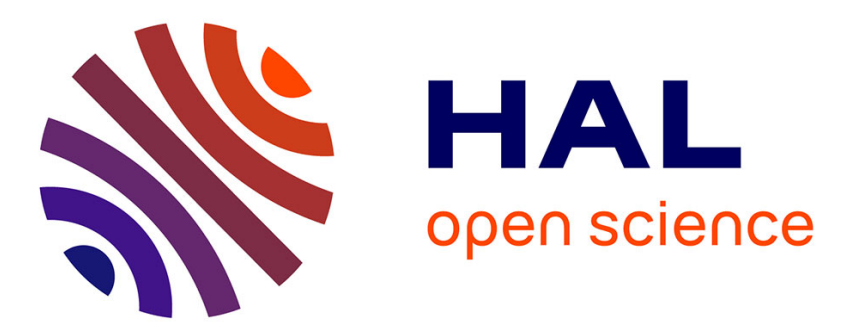

\title{
Susceptibility of the Quercus rubra root system to Phytophthora cinnamomi; comparison with chestnut and other oak species
}

\author{
Benoit Marçais, F. Dupuis, M. L Desprez-Loustau
}

\section{- To cite this version:}

Benoit Marçais, F. Dupuis, M. L Desprez-Loustau. Susceptibility of the Quercus rubra root system to Phytophthora cinnamomi; comparison with chestnut and other oak species. Forest Pathology, 1996, 26 (3), pp.133-143. 10.1111/j.1439-0329.1996.tb00718.x . hal-02080860

\section{HAL Id: hal-02080860 https://hal.science/hal-02080860}

Submitted on 27 Mar 2019

HAL is a multi-disciplinary open access archive for the deposit and dissemination of scientific research documents, whether they are published or not. The documents may come from teaching and research institutions in France or abroad, or from public or private research centers.
L'archive ouverte pluridisciplinaire HAL, est destinée au dépôt et à la diffusion de documents scientifiques de niveau recherche, publiés ou non, émanant des établissements d'enseignement et de recherche français ou étrangers, des laboratoires publics ou privés. 


\title{
Susceptibility of the Quercus rubra root system to Phytophthora cinnamomi; comparison with chestnut and other oak species
}

\author{
By B. MARÇAIS ${ }^{a}$, F. DUPUIS ${ }^{b}$ and M. L. DESPREZ-LOUSTAU ${ }^{b}$ \\ a INRA, Laboratoire de Pathologie Forestière, F54280 Champenoux, France \\ b INRA, Station de Pathologie Végétale, 71 av Edouard Bourleaux BP 81, F33883 Villenave \\ d'Ornon cedex, France.
}

\section{Summary}

Susceptibility of oak seedlings (Quercus palustris, Quercus robur, Quercus rubra) and chestnut seedlings (Castanea sativa) to Phytophthora cinnamomi was tested. The dynamics of infection was examined in plant material raised in a rhizotron. In the oak species, primary root tissues were susceptible whereas secondary cortical tissues showed some resistance to $P$. cinnamomi. Secondary cortical tissues of the tap root in $C$. sativa were susceptible. Inoculations with $P$. cinnamomi were performed both in situ and on excised roots of mature $Q$. rubra. In both cases, the resistance of $Q$. rubra roots and shoots was negatively correlated with diameter at the inoculation point. Small roots $(1-5 \mathrm{~cm}$ diameter) were resistant whereas collar and trunk were susceptible. In contrast to oak, small excised roots of mature $C$. sativa $(0.7-2 \mathrm{~cm}$ diameter) were susceptible to $P$. cinnamomi. This may explain why $P$. cinnamomi does not induce a decline of the attacked red oaks, but rather a trunk canker.

\section{Résumé}

Nous avons testé la sensibilité à Phytophthora cinnamomi de semis de chênes (Quercus palustris, Quercus robur, Quercus rubra) et de châtaigniers (Castanea sativa). La dynamique de l'infection du pivot a été suivie en rhizotrons. Chez les chênes, les tissus primaires de la racine étaient sensibles au parasite alors que les tissus corticaux secondaires présentaient une résistance à $P$. cinnamomi. Chez le châtaignier, les tissus corticaux secondaire du pivot étaient sensibles. Des inoculations par $P$. cinnamomi ont été réalisées sur racines détachées ou en place de chênes rouges adultes $(Q$. rubra). Dans les deux cas, la taille de la lésion induite par $P$. cinnamomi était négativement corrélée au diamètre de la racine inoculée. Les petites racines, de 1 à $5 \mathrm{~cm}$ de diamètre, étaient résistantes alors que les tissus corticaux du collet et du tronc étaient sensibles au parasite. A la différence du chêne rouge, les petites racines détachées de châtaigniers, de 0.7 à $2 \mathrm{~cm}$ de diamètre, restent sensiblent à $P$. cinnamomi. Ceci pourrait expliquer pourquoi $P$. cinnamomi ne fait pas dépérire les chênes rouges qu'il infecte et induit plutôt la formation d'un chancre. 


\section{Introduction}

The role of Phytophthora cinnamomi Rands as the causative fungal agent of ink disease in Quercus rubra L. (red oak) was first demonstrated in the early fifties by ROL (1951) and MOREAU and MOREAU (1951). The main symptom of ink disease is a cortical canker on the lower part of the trunk, which first appears at the collar and then spreads vertically to a height of 1 to $2 \mathrm{~m}$ from soil level. $P$. cinnamomi infection results in necrosis of the cambial and phloem tissues. The response of oak to infection is a relatively efficient limitation in the tangential spread of the pathogen and a healing of the wound tissue, causing the inclusion of the lesion within the wood. The structural damage caused leads to a significant loss in timber value.

Symptoms induced by $P$. cinnamomi on red oak are different to those usually associated with this pathogen (ZENTMYER 1980). On most hosts, P. cinnamomi causes a die-back as a consequence of root damage. In red oak, die-back does not occur and the crown of cankered trees appears normal. Furthermore, RoBIN et al. (1992) have shown that $Q$. rubra infected by this pathogen over a period of 10 to 25 years, has a radial increment of the same order of magnitude as uninfected trees growing at the same site. Ink disease affects mainly trees of more than 10 to 20 years old. $P$. cinnamomi induced root infections in young $Q$. rubra have been reported in nurseries in the United-States (CRANDALL et al. 1945). The fungus may be present on the root system of young oak saplings in Southwest France, though it has not been reported to be a cause of mortality in young stands of planted $Q$. rubra. $P$. cinnamomi can induce very similar disease symptoms on oak species other than red oak. However, in $Q$. robur L. (pedunculate oak) trunk cankers are less frequent than in Q. rubra, and seldom occur in Q. palustris Muench. (pin oak) which has been recorded as field resistant by EDMINSTON (1975).

The aim of the present study was to gain a better knowledge on $Q$. rubra root susceptibility to $P$. cinnamomi which is poorly understood. An attempt was made to explain why infected trees do not die-back such as in the case of most other $P$. cinnamomi hosts. We compared the susceptibility of $Q$. rubra to the more field resistant species $Q$. robur and $Q$. palustris. In addition Castanea sativa (chestnut), a species on which $P$. cinnamomi induces die-back, was examined.

\section{Materials and Methods}

\subsection{Phytophthora cinnamomi isolate}

P. cinnamomi isolate 9 was used for all experiments. It was obtained from trunk cankers of Q. rubra trees in the Basque area (Ainhoa). This isolate has been defined as very aggressive by ROBIN (1991).

\subsection{Rhizotron experiments}

Seedlings were raised from seeds of $Q$. robur (from Orleix, Hautes Pyrénées), Q. palustris (from St. Lezer, Hautes Pyrénées) and C. sativa (from Dol de Bretagne). Following storage at $5^{\circ} \mathrm{C}$ for three months, acorns were shelled and soaked in tap water for $24 \mathrm{~h}$. Seed material was then sown in rhizotrons consisting of plastic containers of $45 \mathrm{~cm}$ depth, $30 \mathrm{~cm}$ length and $3 \mathrm{~cm}$ width. One side of the container was made of glass sealed with a rubber band and covered with a black plastic sheet. The rhizotrons were stacked with their long axis at an angle of $60^{\circ}$ to the vertical, the glass side being on the lower face. At this orientation the seedling roots developed at the interface of the potting medium and the glass. The root system could then be observed non-destructively by removing the black plastic and glass. Seedlings were raised in a glasshouse at a temperature of 
20 to $25^{\circ} \mathrm{C}$ and were watered twice a week with a nutrient solution consisting of $18 \mathrm{mg} . \mathrm{I}^{-1} \mathrm{NH}_{4} \mathrm{NO}_{3}$, $18 \mathrm{mg} . \mathrm{I}^{-1} \mathrm{P}_{2} \mathrm{O}_{5}$ and $14 \mathrm{mg} . \mathrm{I}^{-1} \mathrm{~K}_{2} \mathrm{O}$.

Experiment 1. We used a silty soil obtained from a $P$. cinnamomi infected oak stand (Ainhoa, Pyrénées Atlantiques) as potting medium. Soil was sampled from the top $40 \mathrm{~cm}$, air-dried for two months and crushed until the particules were $3-5 \mathrm{~mm}$ in diameter. Fifteen blocks $4 \mathrm{~mm}$ in diameter were taken from a $P$. cinnamomi mat growing on V8 agar $\left(200 \mathrm{ml} \mathrm{V} 8,2 \mathrm{~g} \mathrm{CaCO}_{3}\right.$ and $20 \mathrm{~g}$ agar in $800 \mathrm{ml}$ distilled water) and added to a $500 \mathrm{ml}$ erlenmeyer flask containing $250 \mathrm{ml}$ of liquid V8 medium. The culture was incubated at $25^{\circ} \mathrm{C}$ on a rotatory shaker $(100 \mathrm{rpm})$ for $48 \mathrm{~h}$. The erlenmeyer flask content was blended with a polytron (15 s at maximum speed), and $20 \mathrm{ml}$ of the inoculum stock solution then diluted with $2 \mathrm{I}$ of tap water and added to $4 \mathrm{I}$ of dry soil. Soil for the control just received tap water.

Fifteen $Q$. rubra seedlings (from Doat, Gers) were grown in the rhizotrons, 12 in 4 rhizotrons filled with $P$. cinnamomi contaminated soil and 3 in a rhizotron filled with control soil. Root growth and lesion development on inoculated roots were recorded on a transparent plastic sheet every 2 to $4 \mathrm{~d}$ during the first month, and then once a week thereafter. As the lesions were restricted to the young white region of the root, they could be observed clearly. When the lesions extended to the older dark region, development was estimated indirectly by recording the appearance of lesions on lateral roots (GRANT and BYRT 1984). On two- to three-month-old seedlings, the lesions could be detected as black necrotic areas against the light brown surface of the taproot. Three months after sowing, seedlings were removed from the rhizotrons, roots washed in running tap water, and all secondary roots removed. The extent of necrotic lesions on the taproot was recorded on the plastic sheets. The taproot was surface-sterilized for $10 \mathrm{~min}$ with $4 \% \mathrm{w} / \mathrm{v}$ calcium hypochlorite, then cut into $1 \mathrm{~cm}$ pieces which were plated on PARB medium $(20 \mathrm{~g}$ agar; $15 \mathrm{~g}$ malt extract; $400 \mu \mathrm{l}$ pimaricin; $250 \mathrm{mg}$ ampicillin; $10 \mathrm{mg}$ rifampicin; $30 \mathrm{mg}$ of $50 \%$ benomyl, 1 I distilled water). Sections that showed an outgrowth of coralloid hyphae after 3-7 days were recorded. This enabled us to determine the distribution and size of the $P$. cinnamomi-induced lesions on the taproot.

Experiment 2. Twenty-four acorns of $Q$. rubra from Doat were sown in rhizotrons containing pure vermiculite (3 acorns per rhizotrons). A $5 \mathrm{~mm}$ diameter agar block, cut from the edge of a $P$. cinnamomi culture grown on a V8 agar plate, was placed on the tip of the taproot 18 days after sowing. Six control seedlings received a sterile block of V8 agar only. Development of necrotic lesions was recorded as described above. Twenty-five days after inoculation, seedlings were removed from the rhizotron and the taproot plated on PARB medium as described above.

Experiment 3. Experiment 2 was repeated, using 21 seedlings of $Q$. rubra (from Vic en Bigorre, Hautes Pyrénées) and 18 seedlings each of $Q$. palustris and $Q$. robur. Three control seedlings per species were inoculated with a sterile block of V8 agar. Plating of the taproot on PARB medium was performed 4 months after inoculation.

Experiment 4. Twelve C. sativa, 10 Q. robur and 24 Q. rubra (from Vic en Bigorre) were grown from seed in rhizotrons containing pure vermiculite. They were inoculated five months after sowing. A $5 \mathrm{~mm}$ diameter agar block was cut from the edge of an active $P$. cinnamomi culture grown on a V8 agar plate and placed on a 3-5 mm wound performed with a scalpel on the taproot, 3 to $5 \mathrm{~cm}$ below the collar. the inoculation point was not sealed. Nineteen days after inoculation the outer bark was removed and the length of discoloured bark determined.

\subsection{Inoculation of adult oaks}

Six mature Q. rubra growing at St. Pée-sur-Nivelle (Pyrénées Atlantiques) were used in this study. Trunk diameters at breast height ranged from 30 to $60 \mathrm{~cm}$. As spacing between trees was very large, the main branches started low, at 2-3 m from soil level. During spring (31 May 1990), trees were inoculated with $P$. cinnamomi, at several levels, in order to compare root and shoot 
susceptibility and to study the influence of organ diameter. At both root and shoot level, five diameter classes were defined, i.e., A, $1 \mathrm{~cm}$; $B, 2 \mathrm{~cm}$; C, $3-5 \mathrm{~cm} ; \mathrm{D}, 7-15 \mathrm{~cm}$; and $E$, trunk or collar. For each tree, four replicates were performed for each organ (root or shoot) $x$ diameter class combination, representing a total of 40 inoculation points per tree. Bark was wounded to the cambium with a cork-borer, and a $7 \mathrm{~mm}$ diameter agar block, cut from the edge of an active $P$. cinnamomi culture grown on a V8 agar plate, was placed with the mycelium in contact with the wood. On small organs, i.e., of less than $5 \mathrm{~cm}$ diameter, the inoculation point was protected from desiccation with wet sterile cotton wool wrapped with parafilm. On larger roots and shoots, the wet sterile cotton wool was covered with aluminium sheet and plastic film fastened with glue. Sterile V8 agar blocks were used for control inoculations.

One and four months after inoculation, lesion length was determined non-destructively using a Plant Impedence Ratio Meter (PIRM, Biosensor, Melbourne, Australia), using a method adapted from TIPPETT and BARCLAY (1987). For shoots of class A and B, the necrotic lesion was measured externally at the first examination. Shoots and roots of class A were sampled at the second examination and the length of discoloured tissues was subsequently measured in the laboratory after removing the bark. Finally at 15 months following inoculation, bark was removed with a chisel from around the inoculation points of shoots and roots from all diameter classes and the length of the discoloured tissues measured. The percentage of lesions which continued to increase in size between the fourth and the 15th month was subsequently calculated for each root and shoot diameter class. Hereafter, these lesions will be refered to as 'unconfined' lesions.

\subsection{Inoculation of excised oak and chestnut roots}

In July 1990, 23 roots of 0.5 to $7 \mathrm{~cm}$ in diameter, from 5 Q. rubra, were dug out and sampled at Pierroton (Gironde). They were cut in segments of about $20 \mathrm{~cm}$ long and washed under tap water. Inoculations with $P$. cinnamomi were carried out as described previously on trees. Roots were then wrapped in aluminium sheet and incubated at $25^{\circ} \mathrm{C}$ in a closed box containing wet vermiculite. Fourteen days after inoculation the bark was removed and the length of discoloured tissues measured. Pieces of discolored bark were plated on PARB medium. This experiment was repeated in August 1990 with 20 roots segments from 7 Q. rubra and 14 roots segments from 5 C. sativa sampled at St. Pée-sur-Nivelle, and again in August 1992 with 21 root segments sampled at Pierroton on 4 C. sativa.

\subsection{Statistical analysis}

The results of inoculation on mature oak and of rhizotron experiment 3 were analysed by a completely randomized variance analysis. When two treatments were studied, the Student t-test was used. Likelihood-ratio chi-square $\left(\mathrm{G}^{2}\right)$ was used to compare the percentage of unconfined lesions after four months for the various organ diameter classes (roots and shoots) on mature oak trees. Pearson coefficient of correlation were used. A SAS/STAT statistical package was used for the calculations (SAS INSTITUTE INC. 1988).

\section{Results}

\subsection{Dynamics of root infection in Q. rubra seedlings}

During rhizotron experiment 1 necrosis first appeared on the taproot tip. No infection was noticed on roots in the control rhizotron. Root infection dynamics were similar in the first three rhizotron experiments (Table 1). At the beginning of infection (stage 1), lesion development was rapid (9 $12 \mathrm{~mm}^{-1}$; Table 1). Two days after inoculation taproot growth ceased though the lateral roots developed as in the controls. 
Table 1. Susceptibility of oak seedlings to $P$. cinnamomi: summary of rhizotron experiments 1,2 and 3

\begin{tabular}{|c|c|c|c|c|c|}
\hline & Exp. 1 & Exp. 2 & \multicolumn{3}{|c|}{ Exp. 3} \\
\hline Inoculation method & $\begin{array}{l}\text { Potting } \\
\text { medium a }\end{array}$ & $\begin{array}{l}\text { Root tip } \\
\text { inoculation }\end{array}$ & \multicolumn{3}{|c|}{ Root tip inoculation } \\
\hline Duration of the experiment & 3 months & 25 days & \multicolumn{3}{|c|}{4 months } \\
\hline Inoculated species & Q. rubra & Q. rubra & Q. rubra & Q. palustris & Q. robur \\
\hline Number of inoculated seedlings & 12 & 18 & 18 & 15 & 15 \\
\hline \multicolumn{6}{|l|}{$\begin{array}{l}\text { Growth rate of } P \text {. cinnamomi } \\
\left(\mathrm{mm}^{-1} \mathrm{~d}^{-1}\right):\end{array}$} \\
\hline $\begin{array}{l}\text { During phase } 1 \mathrm{~b} \text { : } \\
\text { (0-7 days after inoculation) }\end{array}$ & $12.2 \pm 3.0$ & $9.9 \pm 1.4$ & $9.2 \pm 1.5 \mathrm{a}$ & $9.2 \pm 2.6 \mathrm{a}$ & $3.8 \pm 1.0 \mathrm{~b}$ \\
\hline $\begin{array}{l}\text { During phase } 2 \mathrm{~b} \text { : } \\
\text { (7-21 days after inoculation) }\end{array}$ & $0.8 \pm 0.5$ & $1.4 \pm 0.3$ & $1.3 \pm 0.6 \mathrm{a}$ & $0.3 \pm 0.2 b$ & $0.6 \pm 0.3 b$ \\
\hline $\begin{array}{l}\% \text { seedlings having re-established } \\
\text { a taproot } 3-4 \text { month after } \\
\text { inoculation } \mathrm{C}\end{array}$ & $75 \%$ & - & $85 \%$ & $95 \%$ & $95 \%$ \\
\hline $\begin{array}{l}\% \text { of dead seedlings at } 3- \\
4 \text { months after inoculation }\end{array}$ & $16.7 \%$ & - & $10 \%$ & $0 \%$ & $0 \%$ \\
\hline
\end{tabular}

${ }^{a}$ Contamination of the potting medium

${ }^{b}$ Growth rate followed by the same letter are not different at $p=0.05$ using Newman-Keuls range test. Means are followed by standard errors.

${ }^{c}$ See figure 1.

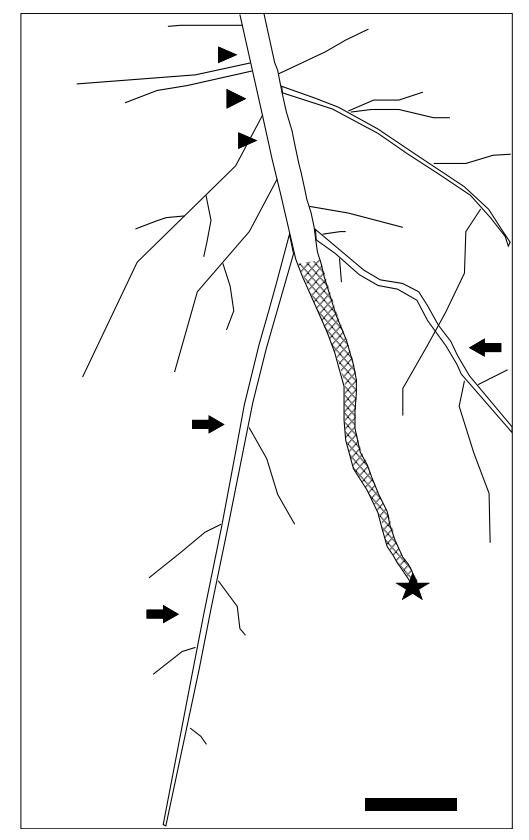

Fig. 1. Root system of a Q. rubra seedling four months after inoculation with $P$. cinnamomi in a rhizotron: old necrotic taproot ( $\mathbb{X})$; inoculation point $(\star)$ ); new taproot $(\Rightarrow)$ ); parts of the taproot where secondary lesions can be found ( $)$. The bar represents $2 \mathrm{~cm}$.

A second stage of infection began 7 - 12 days after inoculation. Lesion development was

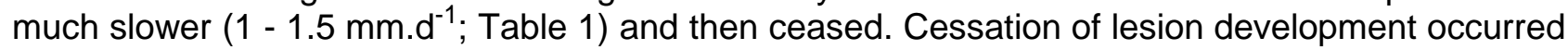
when the necrotic margin arrived in the region of the root where development of the secondary tissues caused darkening of the root surface. In many lateral roots, necrosis began at the tip. In 
the majority of seedlings, lateral root growth almost ceased during the second stage of infection. At the end of experiment 2, seedlings were removed from the rhizotron in an attempt to reisolate $P$. cinnamomi during this stage, $26 \mathrm{~d}$ after inoculation. There were no significant differences between the length of necrotic lesion recorded on the plastic sheet and the length of tissues yielding $P$. cinnamomi on the lower part of the taproot $(\mathrm{t}=1.85 \mathrm{df}=13)$. However, the pathogen could also be recovered from regions of the taproot where no lesions had been recorded on $67 \%$ of the seedlings. These regions were often near the collar, at the base of the lateral roots and there was no connection between them and lesions of the lower part of the root.

A third stage of infection began approximately $30 \mathrm{~d}$ after inoculation. New lateral root growth could be observed again. Though necrosis of lateral root tips could still be observed, $75-85 \%$ of the seedlings re-established a new taproot (Table 1, Fig. 1). Infection of all the new lateral roots prevented recovery of the $15-25 \%$ remaining seedlings and of those, $10-17 \%$ died (Table 1 ). When the seedlings were taken out of the rhizotron at the end of the experiment, most of the lesions on the taproot were healing (presence of wound-callus curls). Some lesions were recorded on the upper part of the taproot, mostly at the base of lateral roots on $30-50 \%$ of $Q$. rubra seedlings (Fig. 1). These lesions were also healing.

\subsection{Behaviour of chestnut and other oak species in the rhizotron}

During experiment 3, there appeared to be little difference in the behaviour of the three oak species to $P$. cinnamomi infection. $Q$. robur was significantly less susceptible than $Q$. palustris and $Q$. rubra during the first stage of infection in the 7 days following inoculation (Table 1 ). After 7 days, there was no more differences between $Q$. palustris and $Q$. robur and only $Q$. rubra was significantly more susceptible.

During experiment 4 , there were significant differences in susceptibility to $P$. cinnamomi among the three species. $Q$. robur and $Q$ rubra showed a low susceptibility whereas $C$. sativa was significantly less resistant. Nineteen days after inoculation, pathogen growth rates on taproots of C. sativa, $Q$. robur and $Q$. rubra were $4.1 \pm 0.8 \mathrm{~mm}^{-1} \mathrm{~d}^{-1}, 0.7 \pm 0.4 \mathrm{~mm} . \mathrm{d}^{-1}$ and $0.5 \pm 0.1 \mathrm{~mm} . \mathrm{d}^{-1}$ respectively. Moreover, C. sativa roots were often girdled, resulting in up to $50 \%$ seedling mortality. This mortality did not occur in oak. During this experiment root tip necrosis was not observed in either of the two oak species.

Table 2. Analysis of variance: growth of $P$. cinnamomi in cortical tissues of $Q$. rubra within 4 months after inoculation

\begin{tabular}{|c|c|c|c|c|}
\hline Source & DF & SS & $\mathrm{F}$ & $P>F$ \\
\hline $\begin{array}{l}\text { Model } \\
\text { Error }\end{array}$ & $\begin{array}{r}59 \\
172\end{array}$ & $\begin{array}{r}15032.8 \\
2700.5\end{array}$ & 16.2 & 0.0001 \\
\hline Diameter a & 4 & 6075.8 & 96.8 & 0.001 \\
\hline Organ b & 1 & 1783.9 & 113.6 & 0.001 \\
\hline Tree & 5 & 1606.9 & 20.5 & 0.001 \\
\hline Diameter $x$ Organ & 4 & 171.8 & 2.74 & 0.031 \\
\hline Diameter x Tree & 20 & 3233.2 & 10.3 & 0.001 \\
\hline Organ x Tree & 5 & 160.4 & 2.0 & 0.075 \\
\hline $\begin{array}{l}\text { Organ } x \text { Diameter } x \\
\text { Tree }\end{array}$ & 20 & 244.4 & 0.78 & 0.737 \\
\hline
\end{tabular}

${ }^{a}$ Diameter class of the inoculated roots or shoots $(A: 1 \mathrm{~cm} ; \mathrm{B}: 2 \mathrm{~cm} ; \mathrm{C}: 3-5 \mathrm{~cm}$; :

7-15 cm; E: trunk or collar).

${ }^{\mathrm{b}}$ Roots or Shoots. 


\subsection{A comparison of root and shoot susceptibility in mature $Q$. rubra}

The root and shoot diameter correlated significantly with the width of the infected cortical tissues $(r=0.912, d d l=227)$. The lesions due to $P$. cinnamomi on the small roots of mature trees appeared very similar to those observed on the 4-month-old seedlings in the rhizotrons: the fungus induced narrow lesions which extended along the length of the organs, but did not girdle the roots. Table 2 shows the results of a variance analysis of lesion length on the mature $Q$. rubra four months after inoculation. Tree root or shoot diameter at the inoculation point, type of organ (shoot or root) and diameter class $x$ tree interactions all caused significant variations in lesion size. Susceptibility to P. cinnamomi increased with the diameter of the inoculated organ (Fig. 2). After more than one month following inoculation, lesion developpment was high only at the trunk and collar level (diameter class E, Fig. 2 b). Roots were less susceptible to $P$. cinnamomi than shoots (Fig. 2 a) though this was true only during the first month following inoculation: thereafter no further differences were apparent (Fig. 2 b).

\section{Lesion development $\left(\mathrm{mm} \cdot \mathrm{d}^{-1}\right)$}

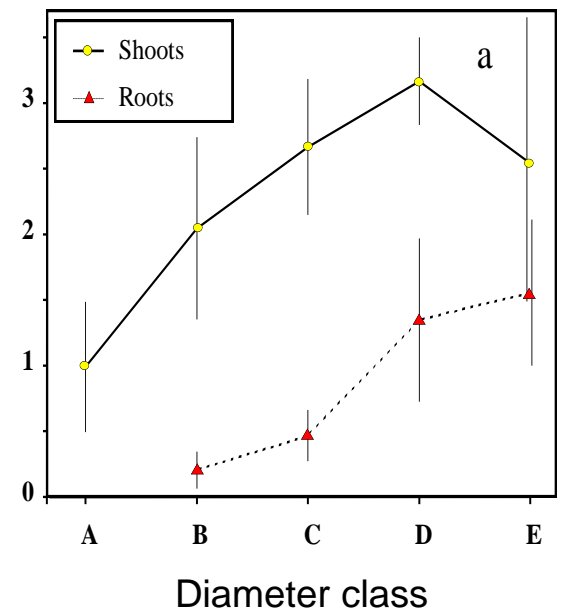

\section{Lesion development $\left(\mathrm{mm} \cdot \mathrm{d}^{-1}\right)$}

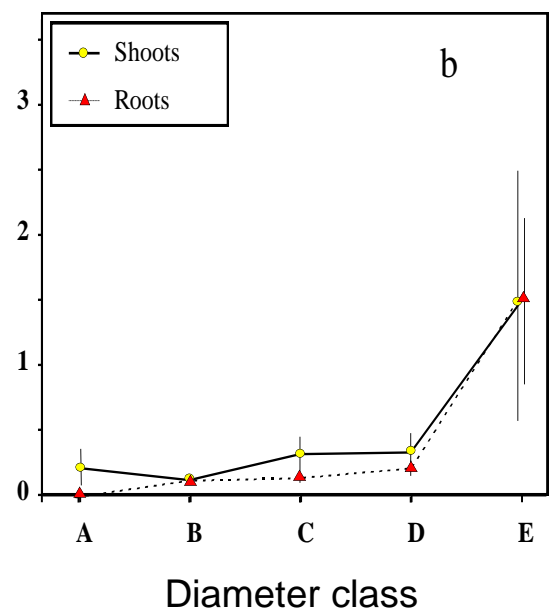

Fig. 2. Lesion lenght on different diameters of $Q$. rubra stem or root inoculated with $P$. cinnamomi (St. Pée-sur-Nivelle, 1990). Means are calculated per diameter class, including results from all trees. Bars represent standard deviation. A: $1 \mathrm{~cm}$; B: $2 \mathrm{~cm}$ diameter; C: $3-5 \mathrm{~cm}$; D: 7-15 cm; E: trunk and collar. a: One month after inoculation. b: Increase between 1 and 4 months.

All lesions were confined after four months on roots of diameter classes $B$ and $C$, and on shoots of diameter classes B, C and D. In contrast, after four months, the percentage of unconfined lesions on the trunk, collar and roots of diameter class D were 50.0, 41.2 and $17.4 \%$ respectively, and were not significantly different from each other $\left(G^{2}=3.08, . d d l=2\right)$. The increase in lesion length in the unconfined collar lesions was $13 \pm 7.2 \mathrm{~cm}$ at four months and $24.5 \pm 10.6 \mathrm{~cm}$ at 15 months. No roots or shoots of any diameter was girdled by $P$. cinnamomi 15 months after inoculation.

\subsection{Inoculation of excised oak and chestnut roots}

During both experiments in 1990, the lesion length induced by $P$. cinnamomi on excised roots of Q. rubra was significantly correlated with root diameter at the inoculation point $(r=0.763$ and $r=0.668$ ). A similar result was obtained for excised roots of $C$. sativa in the 1992 experiment $(r=0.787)$, but not in the 1990 experiment $(r=0.03)$. During both experiments, $P$. cinnamomi 
growth rate was low on small excised $Q$. rubra roots of about $1 \mathrm{~cm}$ diameter, compared to small excised C. sativa roots (Fig. 3 a and b).
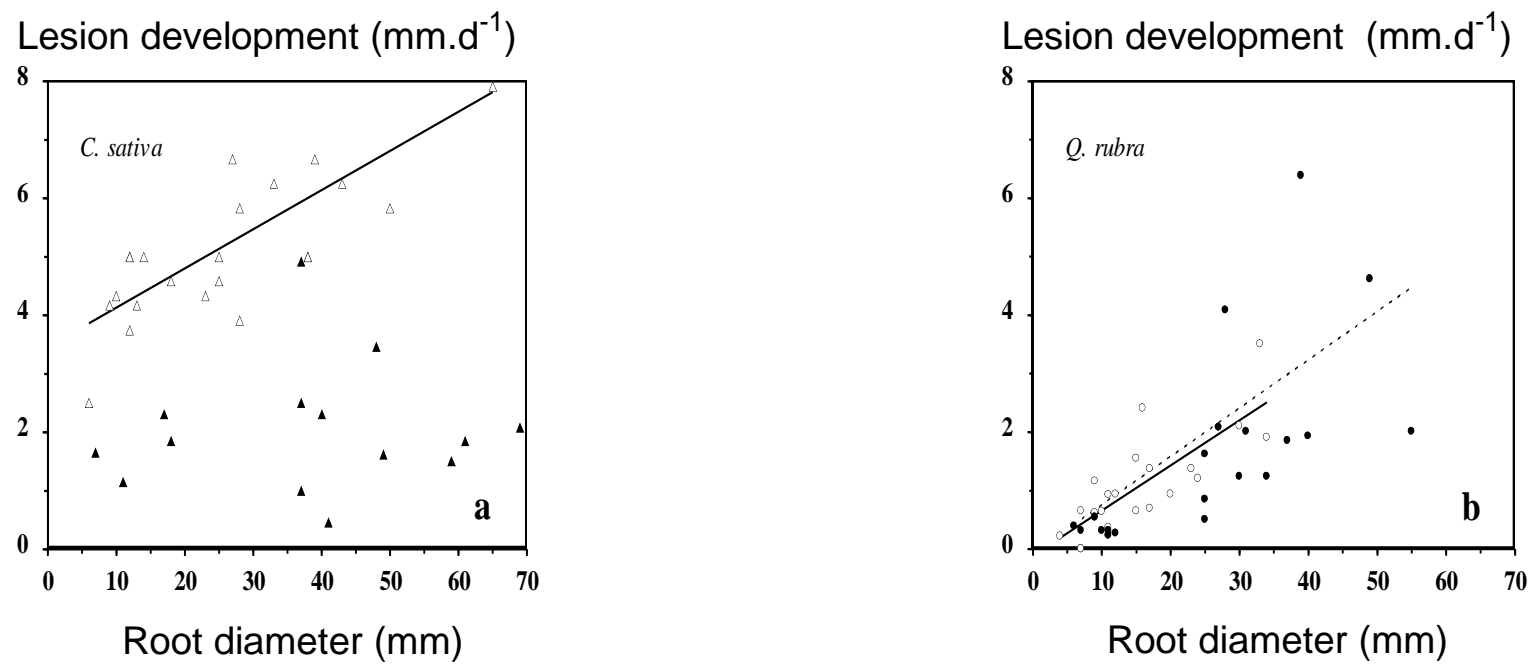

Fig. 3. Lesion length on excised roots of $C$. sativa and $Q$. rubra inoculated with $P$. cinnamomi. Experiments of July 1990 and of August 1992 are displayed with opened symbols (solid regression line) and experiment of August 1990 with closed symbols (dotted regression line). LD is the lesion development, in $\mathrm{mm}^{-1} \mathrm{~d}^{-1}$ and $\mathrm{RD}$, the root diameter, in $\mathrm{cm}$.
a. $L D=3.46( \pm 0.35)+0.067( \pm 0.012) \times R D ; r^{2}=0.619$ (August 1992)
b. $L D=-0.11( \pm 0.23)+0.077( \pm 0.013) \times R D ; r^{2}=0.630$ (July and August 1990)

\section{Discussion}

The rhizotron experiments suggested that $P$. cinnamomi enters $Q$. rubra seedlings via root tips which is in agreement with current literature (ASSAS M'BILLAUT 1978; HO and ZENTMYER 1977; TIPPETT et al. 1976). Root infection then proceeds in three stages on Q. rubra seedlings: (i) $P$. cinnamomi grows along the taproot in the absence of any apparent seedling reaction, (ii) growth of oak roots, and subsequently the rate of pathogen advance, slows down and gradually ceases, followed by (iii) a resumption of seedling root growth. In a few cases, $P$. cinnamomi advance is not halted and the oaks die (10\% of the seedlings). This behaviour of $Q$. rubra is similar to that of the field resistant Eucalyptus calophylla Lindley and 'Duke 7' Avocado rootstock after inoculation with P. cinnamomi in a rhizotron (GRANT and BYRT 1984; PHILLIPS et al. 1987). This may explain why this pathogen does not induce die-back in oak.

Pathogen advance along the taproot ceases at the point where the secondary tissues develop. The secondary tissues appear to have low susceptibility to $P$. cinnamomi since pathogen growth rate during the 19 days following inoculation was only $0.5 \pm 0.1 \mathrm{~mm}^{-1} \mathrm{~d}^{-1}$ (experiment 4 ) compared to $3.9-4.6 \mathrm{~mm}^{-\mathrm{d}^{-1}}$ for primary tissues (Table 1). The explanation for the greater resistance at the level of the secondary tissues in $Q$. rubra roots is not known. Necrophylactic periderm which is specific to secondary tissues has been shown to be an important resistance mechanism of trees to cortical pathogens (BIGGS 1984; MULLICK 1977). In 'Duke 7' Avocado rootstock, susceptibility to $P$. cinnamomi is less in secondary than in primary tissues and resistance is linked to the development of necrophylactic periderm (PHILLIPS et al. 1987). In contrast to avocado, secondary roots tissues of E. marginata (Donn. ex Smith) are more susceptible than primary roots tissues (TIPPETT and HILL 1984). 
The infection of lateral root tips by $P$. cinnamomi during experiments $1-3$ indicates that secondary inoculum production occurs, though this was not demonstrated by reisolation of the fungus in the potting medium. The absence of root tip infection during experiment 4 suggests that secondary inoculum production occurs only at the primary tissue level. The lesions found on the upper part of the taproot (Fig. 1) are probably due to secondary infections of the seedlings as they are located at the bases of lateral roots and are not continuous with the lesion of the lower part of the taproot. Death of oak seedlings during stages 2 and 3 is likely to be a consequence of these secondary infections. The potting medium used (pure vermiculite) together with the orientation of the rhizotrons $\left(60^{\circ}\right.$ to the vertical) did not allow good drainage and may therefore have favoured a significant infection of the oak root system by the secondary inoculum produced and breakdown of the seedlings resistance.

During the field experiment, after a short initial period, one month after inoculation, the $Q$. rubra root system and shoot systems show a similar susceptibility to $P$. cinnamomi (Fig. $2 b$ ). A comparison of in situ and excised roots of $Q$. rubra (Figs. 2 and 3 ) shows that the susceptibility of cortical tissues to $P$. cinnamomi is closely related to host organ diameter at the inoculation point. The mature trees examined are susceptible to this pathogen mainly at the trunk and collar level (Fig. 2b), i.e. the organ on which symptoms can be observed in natural conditions. In contrast small roots are resistant to $P$. cinnamomi (Figs. 2 and 3), though inoculations were performed at the end of May, a time when susceptibility of oak cortical tissues is maximal (ROBIN 1994). The fungus was not able to girdle the oak roots or shoots, whatever their diameter. This may explain why $P$. cinnamomi does not cause mortality of $Q$. rubra trees. In contrast, the fungus was able, within two summers, to girdle the roots of E. marginata and induce die-back (TIPPETT et al. 1983).

The explanation for the lower susceptibility of small roots and shoots to $P$. cinnamomi is unknown. Organs of various diameters are different in many features, e.g., width and age of the cortical tissues, structure of the inner bark (TROCKENBRODT 1991), radial growth, and physiology. According to TIPPETT et al. (1983), organs of E. marginata with a low radial increment have a different cortical tissue structure than those which grow rapidly, possessing a denser phloem and greater resistance to $P$. cinnamomi. MERRILL and FINLEY (1981) have shown that the susceptibility of Juglans nigra and Sassafrass albidum cortical tissues to Nectria galligena Bres. are dependent on the age of the stem. They attributed this association to the developmental physiology of the stem.

Susceptibility of root secondary tissues was higher for $C$. sativa than for Q. rubra in all experiments. A relationship between diameter at the inoculation point and size of the lesion induced by $P$. cinnamomi on excised $C$. sativa roots is apparent in one out of two experiments, though small $C$. sativa roots $(0.7-2 \mathrm{~cm}$ diameter) still show some susceptibility to the pathogen, in contrast to the resistance of small oak roots (Fig. 3 ). There is unrestricted growth of $P$. cinnamomi in secondary root tissues of $C$. sativa seedlings in rhizotron experiment 4 . The fungus continue to girdle the taproot as shown by the high mortality 19 days after inoculation. These results are in agreement with those of GRENTE (1961) and CRANDALL et al. (1945) which reported percentage mortality of $38 \%$ and $0 \%$ after inoculation of $P$. cinnamomi on young $C$. sativa and $Q$. rubra respectively. Unlike $C$. sativa, the three oak species show some resistance at the level of secondary root tissues. When all studied parameter are considered, the level of resistance to $P$. cinnamomi in $Q$. robur and $Q$. palustris is greater than in $Q$. rubra seedlings (Table 1 ). The results that have been obtained from the rhizotron experiments are in agreement with the recorded field behaviour of the species examined which may be ranked in order of increasing susceptibility to $P$. cinnamomi as follows: $Q$. palustris $=Q$. robur $<Q$. rubra $<$. sativa.

From all our observations, a likely scenario of infection of $Q$. rubra by $P$. cinnamomi could be described as follows. The key problem for the pathogen would be to reach the collar area of its host. As susceptibility of small roots is low, the place where $P$. cinnamomi enter the oak trees is likely to be very close to the collar. It might also be possible that progression of $P$. cinnamomi from the root tips to the collar occurs mainly during limited periods, e.g., during periods of high inoculum 
production (waterlogging) or of lowered host resistance (root anoxia, water shortage). In particular, water stress has been shown to increase the susceptibility of young oak saplings and mature oak trees to $P$. cinnamomi (MARÇAIS et al 1993). In view of the results obtained during this work, it can be concluded that, to test the susceptibility of oak trees to $P$. cinnamomi, the inoculation of the trunk or collar bark would be the best method, as they are the most susceptible part of the tree and are easy to reach.

\section{Acknowledgements}

We thank M. VAN MEER and H. RIVIĖRE for technical assistance and M. DeLATOUR for reviewing the manuscript.

\section{References}

ASSAS M'BILLAUT, G., 1978: La pourriture brune de racines d'avocatier. Etude histologique de la pénétration et de l'infection des racines par Phytophthora cinnamomi Rands. Fruits 33,107-115.

BIGGS, A. R., 1984: Discussion: response of bark tissues to injury and infection. Can. J. For. Res. 14,351356.

Crandall, B.S., Gravatt, G.F., Ryan, M.M., 1945: Root disease of Castanea species and some coniferous and broadleaf nursery stocks, caused by Phytophthora cinnamomi. Phytopathology 35,162-180.

Edminston, R. J., 1975: A selection of species resistant to Phytophthora cinnamomi. For. Focus 14,15.

GRANT, B. R., BYRT, P.N., 1984: Root temperature effects on growth of Phytophthora cinnamomi in the roots of Eucalyptus marginata and Eucalyptus calophylla. Phytopathology 74,179-184

GRENTE, J., 1961: La maladie de l'encre du châtaignier. Ann. Epiphyt. 12,5-59.

Ho, H.H., ZentmyeR, G.A., 1977: Infection of avocado and other species of Persea by Phytophthora cinnamomi. Phytopathology 67,1085-1089.

MARÇAIS, B., DupUIS, F., DeSPREZ-LoustaU, M.L., 1993: influence of water stress on susceptibility of red oak (Quercus rubra) to Phytophthora cinnamomi. Eur. J. For. Path. 23,295-305.

MerRIL, W., FINLEY, R.J., 1981: Relationship of stem tissue age and frequency of Nectria canker. Plant disease 65,66-67.

MoreaU, M., MoreaU, C., 1951: Une grave affection nouvelle de la forêt française : la maladie de l'encre du chêne. Comptes rendus hebdomadaires des séances de l'académie des sciences 232,2252-2253.

MULLICK, B.M., 1977: The non-specific nature of defense in bark and wood during wounding, insect and pathogen attack. Recent Advances in Phytochemistry, 11,395-441.

Phillips, D., Grant, B.R., Weste, G., 1987: Histological changes in the roots of an avocado Cultivar, Duke 7, infected with Phytophthora cinnamomi. Phytopathology 77,691-698.

RoBIN, C., 1991: La maladie de l'encre du chêne rouge Quercus rubra L. causée par Phytophthora cinnamomi Rands : perspectives pour l'amélioration génétique de la resistance. Thèse de doctorat. Université de Bordeaux 2. 140 p.

Robin, C., DupuIS, F., Desprez-Loustau, M.L., 1994: Seasonal changes in Northern Red Oak susceptibility to Phytophthora cinnamomi. Plant Dis. 78,369-374.

Robin, C., Desprez-Loustau, M.L., Delatour, C., 1992: Factors influencing the enlargement of trunk cankers of Phytophthora cinnamomi in red oak. Can. J. For. Res. 22,367-374.

RoL, R., 1951: Le chancre du chêne rouge. Rev. For. Française 11:704-707.

SAS INSTITUTE INC., 1988: SAS/STAT guide for personal computers, version 6.03 edition. SAS Institute Inc., Cary, NC.

TIPPETT, J.T., BARCLAY, J.L., 1987: Detection of bark lesions caused by Phytophthora cinnamomi in Eucalyptus marginata with the impedance ratio meter and the Shigometer. Can. J. For. Res. 17,12281233.

TIPPETT, J.T., HILL, T.C., 1984: Role of periderm in resistance of Eucalyptus marginata roots against Phytophthora cinnamomi. Eur. J. For. Path. 14,431-439. 
Tippett, J.T., Holland, A.A., Marks, G.C., O'Brien, T.P., 1976: Penetration of Phytophthora cinnamomi into disease tolerant and susceptible Eucalypts. Arc. Microbiol. 108,231-242.

TippetT, J.T., SheA, S.R., HiLl, T.C., SheARER, B.L., 1983: Development of lesions caused by Phytophthora cinnamomi in the secondary phloem of Eucalyptus marginata. Aust. J. Bot. 31,197-210.

TROCKENBRODT, M., 1991: Qualitative structural changes during bark development in Quercus robur, Ulmus glabra, Populus tremula and Betula pendulata. IAWA Bulletin n.s. 12,5-21.

Zentmyer, G.A., 1980: Phytophthora cinnamomi and the diseases it causes. Monograph No.10. American Phytopathological Society, St Paul. 